\title{
Spatial Assessment of 2014-flood Disaster and Extent of Associated Damages in Lower Chenab Basin, Upper Indus Plain, Pakistan
}

Shakeel Mahmood ( $\nabla$ shakeelmahmoodkhan@gmail.com )

Lahore https://orcid.org/0000-0001-6909-0735

Razia Rani

Department of Geography, Government College University Lahore

Research Article

Keywords: Riverine Flood, Causes, Damages, Indus Plain, CBDRM, GIS, Remote Sensing

Posted Date: April 14th, 2021

DOI: https://doi.org/10.21203/rs.3.rs-409419/v1

License: @ (1) This work is licensed under a Creative Commons Attribution 4.0 International License. Read Full License 


\section{Abstract}

This study is an effort of spatial assessment of 2014-flood and associated damages in Upper Indus Plain (UIP). Community Based Disaster Risk Management (CBDRM) approach in integration to geo-spatial techniques is implemented to assess the nature and damages as well as community perception in reducing floods. In this regard, a semi-structured questionnaire was designed for micro-level detail investigation. A total of 422 households were surveyed in 22 flood affected villages in eight districts forms the lower Chenab Basin using random sampling techniques. Secondary data regarding river discharge is collected from Regional Meteorological Centre, Lahore. Shuttle Radar Topographic Mission (SRTM) Digital Elevation Model (DEM) having 30m spatial resolution and Landsat satellite image of September 2014 with same resoluation is acquired from open source geo-database of United States Geological Survey (USGS). Landsat satellite image is processes to extract the spatial extent of inundation. Watershed modelling approach is utilized to demarcate Chenab River Basin in GIS environment. Buffer analysis and Inverse Desistance Weighted (IDW) technique of spatial interpolation are used to geo-visualize the spatial extent and depth of flood based on community perception. Analysis reveals that flood is one of the recurring phenomena in Chenab Basin. The upper catchment areas of Chenab Basin are dominated by flash floods and low-lying areas are prone to riverine floods. The 2014-flood has caused estimated economic damage of 1409.295 million Pakistani Rupees (mPKR). Housing sector suffered the major losses of more than $1000 \mathrm{mPKR}$ followed by agricultural sector. Based on spatial extent, vertical profile and damages the study region is categorised into upper and lower zones. The lower zone is most affected in terms of extent, depth and damages. This study can assist the decision makers and disaster managers in designing location specific flood risk reduction.

\section{Introduction}

Worldwide, flood is one of the worst hydro-meteorological disasters causing socio-economic, environmental and physical damages (Rahman \& Khan 2011; Mahmood et al. 2019a). Commonly, heavy rainfall accompanies by melting of snow and glaciers leading to floods. Its further development is influenced by intensity of rainfall, hydrological response and geo-morphometric character of the basin (Mahmood and Rahman 2019b).

Meteorologically, rising intensities of heavy rainfall events are increasing the frequency and magnitude of floods (Booij 2005). Similarly, excessively melting of snow and glaciers due to rising global temperature (Kosaka \& Xie 2013) and clearing of green cover further intensified the phenomena (Gholami et al. 2009; Rahmen \& Khan 2013). The risk of climate change has increase the flood risk (Hirabayashi et al. 2013). It is also clear from the recent scientific literature that the frequently occurring extreme precipitation episodes will increase the devastating floods (Mahmood \& Rahman 2019b). The rainfall directly contributes water to the drainage system in basin (Dawood et al. 2020). In this perspective, trend in rainfall has significant impact on genesis of floods (Beyene et al. 2010). The current climate change exacerbation has been a major concern due to its projected impacts on socio-economic and physio-ecological system (Vetter et al. 2017). However, number of anthropogenic activities turn the floods more destructive (Dong et al. 2009). The impacts of floods on a global scale are enormous (Jonkman et al. 2008). Annually, flood disaster is resulting in over 20000 life loss and reflective property loss (Mahmood \& Razia 2018). During the 20th century, floods have taken lives of 8 million people (Jonkman 2005). The ten disastrous floods from 1980 to 2010 has caused 13393 fatalities and 149600 million US\$ losses (Mahmood et al. 2016a).

In Pakistan, high magnitude floods were more frequent particularly in the last two decades due to diversity in hydro-meteorological and geographical conditions (Mahmood et al. 2016b; Mahmood et al. 2019a,b). The heavy 
Monsoon rainfall and melting of snow/glaciers in the mountainous north generate floods (Shamshad 2011; Houze et al. 2011). The Monsoon contributes about 60-70\% in total rainfall (Kakar 2010; Wang et al. 2011; Hashmi et al. 2012; Hussain \& Lee 2014). Temporally, this season extends from June to September with maximum rainfall in July and August resulting in damaging floods (Rahman and Shah 2012). The extraordinary activity of Monsoon, poor preparedness and lack of suitable flood mitigation structural measures in the Indus Plain are leading to devastating floods (Zaman \& Afzal 2013; Khan et al. 2014; Mahmood et al. 2019a). Consequently, the individual, household and community vulnerabilities have been grown (Ouma and Tateishi 2014). The varying demographic conditions, socio-economic status and human economic activities in the proximity of active flood plain have further intensified vulnerability to floods leading to high risk (Aggarwal 2016; Mahmood and Hamayon 2021).

In the year 2010, a disastrous flood hit the country and anthropogenic activities over the past years in Indus Plain further strengthen the damaging charater of flood and caused human life losses, damages to buildings, infrastructure and agricultural sector with huge economic loss (Hauze et al., 2011; Mahmood et al., 2016a,b). More than 1850 people lost their precious lives, tens of billions US\$ economic loss occurred, affected above 20 percent of the total land area and about 15 million people (Mahmood 2019). The spatial extent, depth and duration of flood with direct effect was uneven because of spatial variation in landscape, land use/Land cover and population density (Mahmood et al., 2019b). Likewise, in the year 2014, extraordinary activity of late Monsoon (September) caused massive flood in upper Indus Plain particularly in lower Chenab Basin. The recorded peak was 0.45 million cusecs with physical and economic damages. These were the most destructive floods in Pakistan (Mahmood and Razai 2018). The surface hydrology of Indus Basin, spatial extent of 2010-flood, damages and causative factors of flooding have already been published and discussed by number of researchers few are (Gaurav et al. 2011; Manzoor et al., 2013; Syvitski and Brakenridge 2013; Arslan et al. 2013; Khan et al. 2014). Hashmi et. al. (2012) carryout a detail study on carring capacity of rivers and barrages in Pakistan. He also finout the role barrages and inundation canals in flood mitigation. Mahmood et al. (2019b) assessed the 2010-flood causative factors and spatial extent of damages in central Indus Basin. Mahmood et al. (2021) also assessed the cause and damages of the 2010-flood disaster in Central Indus Basin.

In this study, 2014-flood flood disaster and the extent of associated damages in upper Indus Plain are spatially assessed using integrated geo-spatial techniques and Community Based Disaster Risk Management (CBDRM) approach. Place-based concept of vulnerability is used to investigate the nature of past floods as suggested by (Mahmood and Hamayon 2021). For detail micro-level analysis, 22 flood affected villages were randomly selected from eight districts located spatially distributed over the right and left banks of Chenab River in $8 \mathrm{Km}$ buffer zone. Based on community perception, flood depth, its spatial extent and socio-economic conditions were analysed. Alongside, hydrological behaviour of the river during flood is visualized. The integrated approach of Geographic Information System (GIS), satellite data, Global Positioning System (GPS) and field surveys are used as monitoring tools in the process of spatial assessment for gei-visualization of flood and associated damages.

\section{The Study Region}

Geographically the Lower Chenab Basin extends from $30^{\circ} 36^{\prime} 7.2^{\prime \prime} \mathrm{N}$ to $32^{\circ} 49^{\prime} 40.8^{\prime \prime} \mathrm{N}$ latitude and $73^{\circ} 43^{\prime} 40.8^{\prime \prime} \mathrm{E}$ to 7457'3.6"E longitude. Administratively, the study region includes the districts of Gujrat, Sailkot, Gujranwala, Mandibahudin, Sarghodha, Hafizabad, Chinot and Jhang. The research of Chenab River extends from Head Marala is located in the north to Head Trimmu in the south (Fig. 1). Chenab River is one of the main eastern tributaries of Indus River System which undergoes intensive inundation almost every year during the late monsoon 
period (Ali, 2013). The length of Chenab River is $274 \mathrm{Km}$ in Pakaistan. The total catchment area Chenab Basin is $41656 \mathrm{Km}^{2}$ out of which $27195 \mathrm{Km}^{2}$ is mountainous catchment area in upstream of Head Marala which is dominated by flash floods and lowlying areas are characterised by riverine floods. It enters Pakistan at Marala Headwork with annual average discharge of 26.7 million acre feet (MAF). The mean monthly water discharge is above 62000 cusecs in July and August while in September is less than 50000 cusecs (Mahmood and Razia, 2018 ) .

The Upper Indus Palin is a fertile land that supports the livelihood of millions of people. They are engaged in variety of economic activities particularly agriculture. Agricultural activities are successful with maximum production because of the availability of fertile alluvium and canal irrigation system. Therefore most of the local residents have their source of revenue from agricultural activities. The major cultivated crops are rice, sugarcane, maize, cotton, fodder and beans. Mostly, people are living in bricks and mud houses which are non-resilient to flood. The housing condition and lower per month income has made the exposed communities susceptibility to floods.

\section{Data Acquisition And Analysis}

Community Based Disaster Risk Managemnt (CBDRM) approach in integration with Geo-spatial techniques is implemented to spatially assess the 2014-flood disaster and associated damages. In this regard, a semi-structured questionnaire was designed for micro-level detail investigation of socio-economic conditions of the residents in flood zone, nature of flood and community perception regarding flood risk reduction in order to minimize future damages. The respondents were asked regarding the socio-economic effects of floods. Consent of every respondent was taken prior to questions. Before the detail field investigations a preliminary survey was conducted in the study region to determined the spatial extent of flood and check the validity of questionnaire. There is nothing related to bioethics therefore ethical approval is not applicable for this study.

Based on preliminary survey results sample villages were selected randomly in define spatial extent (8Km buffer zone) of flood based on community perception. The sample villages were randomly selected from eight (100\%) flood effected districts in lower Chenab Basin (Fig. 1). The sample villages are spatially distributed along River Chenab over left and right banks from Head Marala to Head Trimmu. A total of 422 households were surveyed by simple random sampling technique in the 22 flood effected villages in $8 \mathrm{Km}$ buffer zone. During questionnaire survey the respondents were asked regarding the socio-economic conditions, nature and damages of flood. The socio-economic conditions included age, family size, income and expenditure. Nature of flood included depth, frequency, spatial extent and duration of flood. Damages included damages to houses, standing crops, loss of livestock and agricultural equipments. The respondents were also asked about the estimated rehabilitation cost of damages to determine the total economic loss. The respondents were also asked regarding the flood risk reduction strategies using CBDRM approach.

Secondary data is collected from concerned government departments. Historical record of river discharge is collected from Regional Meteorological Centre, Lahore. Shuttle Radar Topographic Mission (SRTM) Digital Elevation Model (DEM) having 30m spatial resolution and Landsat satellite image of September 2014 with same resolution is downloaded from United States Geological Survey (USGS) open source geo-database. MODIS satellite images were downloaded to extract flood extent by applying supervised image classification technique. The data about affected population, human casualties, livestock casualties, houses damages and crops affected were obtained from Punjab Provincial Disaster Management Authority (PPDMA). 
Watershed modelling approach is utilized to delineate Chenab watershed in GIS environment by using SRTM spatial data as input layer. Buffer analysis technique and CBDRM approach is applied in integration to delineate the spatial extent of flood. Similarly, Inverse Distance Weighted (IDW) technique of spatial interpolation is applied in integration with community perception to model flood depth in defined spatial extent. Descriptive statistical technique is used to process and analyze damages data. Average rehabilitation cost in every sector for one unit is calculated. Then total estimated economic loss is calculated by adding damages in all sectors in million Pakistani Rupees (mPKR). Flood extent was extracted from Landsat satellite image by maximum likelihood image classification technique in GIS environment. The results are presented in the form of maps, tables and graphs.

\section{Results And Analysis}

Riverine floods are more destructive over the Indus Plain because of the fairly flat surface, high population density and dense human economic activities particularly agriculture (Tariq and Giesen 2012). The frequency of extream rainfall events with $150 \mathrm{~mm}$ /day or higher presented a significant positive tendency indicating high risk of potential floods (Ahmad et al. 2015). The study region is also the part of UIP where the spatial assessments of 2014 flood disaster and its associated damages have been made. The details are given in the following sections.

\subsection{Socio-economic status of the Surveyed Households}

The total population of the surveyed households was counted as 3749 persons. Family size of the households is separated into three categories; small, medium and large. The family comprised of parents (father and mother), their kids, niece, nephews, grandfather and grandmother. Medium size families (6 to 10 persons) were around 55.6 percent, while small (less than 6 persons) and large size families (more than 10 persons) were 18.4 percent and 26 percent, respectively. The average family size of the surveyed households was 9 persons with a standard deviation of 5. Likewise, the monthly income of the surveyed households was categorized into three classes i.e. "low income class" <15,000 Pakistani Rupees (PKR), "middle income class" ranging from 15,000-25,000 PKR, and "high income class" $>25,000$ PKR. Out of the total surveyed households 58.3 percent were belong to low income class, around 22.9 percent were of middle income and 18.8 percent were in high income class. More than 90 percent of the respondents were living in mud houses. These non-resilient houses were constructed in flood zone.

\subsection{Genesis of 2014 Flood Disaster}

The spatial pattern of Monsoon rainfall varies across the country from August to September. The Chenab Basin is spatially located in zone having daily average rainfall of $3 \mathrm{~mm}$ per day. But in the year 2014 , the extra ordinary activity of the late (first week of September) Monsoon rainfall particularly over the upper catchment areas of Chenab Basin (Figure 2C) generated high surface runoff and high discharge in rivers. Rain-water together with melt-water in the eastern rivers of Indus System, particularly in Chenab River, resulted in massive flood at Head Marala extraordinary scale, both in terms of magnitude and spatial extent. Along with this heavy runoff, India also released 0.2 million cusecs in the upper catchment area of Chenab River which has caused massive inundation in Lower Chenab Basin (Head Marala to Head Trimmu) with devastating effects. The outflow from Head Marala coupled with runoff from local Nullahs (streams) heightened the flood peak upto 0.95million Cusecs. This unexpected peak hit the Khanki Barrage (designed capacity of 0.8million cusecs) on 7th of September, 2014 early morning. The Punjab Irrigation Department (PID) took a decision to breach the bund (embankment) in order to reduce the risk barrage outburst because the flood peak was high than its capacity. The breaching decision was 
effective because flood water re-entered the river channel without life loss and damages. The flood peak of 0.95million Cusecs was flowing downstream and hit Head Qadirabad (designed capacity of 0.8million cusecs) at 11:00am on same day. The Trimmu Headworks (designed capacity of 0.645 million cusecs) received flood peak of around 0.703 million cusecs on 10th of September at 07:00pm. The planned breaching segment in Right Marginal Bund (RMB) was activated on 10th of September at 10:00am as per policy. The Jhang Flood Protection Bund situated along left bank of Chenab River was burst by the hydraulic pressure of flood peak over two spots resulting in around 0.07 to 0.075 million cusecs flood flow to passed through the breached segments. Finally, high flood stage of 0.455 million cusecs was documented in Chenab River at Panjnad on 16th of September (Figure 3 ). The runoff in ordinary floods remains less than 0.1 million cusecs whereas above 0.6 million cusecs are unusually high flood. The highest runoff in River Chenab at Head Marala was 0.543million cusecs, at Head Qadirabad 0.556million cusecs and at Head Khanki 0.66million cusecs. Therefore, flood in 2014 was announced as high flood stage in lower Chenab Basin.

Consequently, this high flood has damaged standing crops, lifeline infrastructure and villages in the flood zone affecting national economy directly and indirectly badly. Based on the accessible data and estimations, the 2014flood affected approximately 2.6 million people, completely or partially damaged 1.3 million houses and took 387 precious human lives in Chenab Basin. In agricultural sector, about 0.25 million farmers were affected, more than one million acres of cropland with standing cash crops and fodder crops were severely damaged from north (Marala Headworks) to south (Trimmu Headworks) in lower Chenab Basin.

\subsection{Spatial Extent and Depth Level of 2014-Flood}

The spatial extent of 2014-flood was variable from Marala Headworks to Trimmu Headworks in the lower Chenab Basin. The extent of flood increases downstream from Sialkot to Jhang (Fig. 2). The northern region comprised of Gujrat, Sialkot, Gujranwala and Mandi Bahauddin districts with spatial extent of flood ranging from 0.4 to $0.7 \mathrm{~km}$. The southern region includes districts of Hafizabad, Chinot and Jhang. The spatial extent in Hafizabad was $4.2 \mathrm{Km}$ and Jhang $4 \mathrm{~km}$. In Jhang, the estimated spatial extent is on left bank is $3.4 \mathrm{~km}$ while over the right bank $1.2 \mathrm{~km}$. In Sarghodha, extent is minimum (Figure 3).

The spatial variation in flood depth level is also an essential output of the hydrological modelling approach. The vertical profile is important in determining vulnerability to flood. It depends on fluvial morphology and hydraulics of the river channel. In general, the flood depth level is higher in the active channel and lowers towards the banks. The flood depths futher decreases in the inundated areas on both sides depending on the local landscapes. In the selected reach of Chenab River in lower Indus Plain, the vertical profile of the flood is minimum (less than $1.5 \mathrm{~m}$ ) in the northern section of the reach because of low discharge. In the middle section, depth level is variable because of wetted width of active channel and variation in morphology of the channel bed where depth is ranging from $1.5 \mathrm{~m}$ to $3 \mathrm{~m}$. The southern section has maximum flood depth ranging from $3 \mathrm{~m}$ to $4 \mathrm{~m}$ and above. Spatially, flood depth is minimum in Sialkot and Gujrat and maximum in Chinot ( $3 \mathrm{~m}-4 \mathrm{~m})$ and Jhang (4.2m; Figure 4). GIS base flood depth mapping provides a clear picture across and along the river channel. Figure $5 a, b$ is visualizing the pre and post flood conditions of the study region. It is evident from the satellite image that the spatial extent of flood is expanding towards south.

\subsection{Extent of Associated Damages}


The spatial extent, depth and duration of flood have affected communities in the hazard zone. Life losses, damages to human settlements, agricultural sector in the proximity of river were more drastic. The flood damages have been spatially assessed through GPS based questionnaire survey, observations and interviews in the eight selected sample districts. In the entire study region, flood has affected population from north to south. Although the number of affected people directly or indirectly varies. In Sarghodha, affected population is less than 10000 . In Gujrat, Sialkot and Gujranwala the affected population is ranging from 10000-20000 whereas in Jhang more than 40000 people is affected by flood (Figure 5).

Flood has also caused fatalities in the entire study region from north to south. In Gujranwala, Mandi Bahauddin and Sarghodha human losses were minimum whereas in Sialkot it is maximum (Figure 6). In Chinot and Jhang ijuries are maximum due to the maximum spatial extent and depth of flood. Damages to houses are also more because more than $95 \%$ are mud houses which are non-resilient to flood. The spatial extent and depth of flood has affected human settlements badly (Fig. 7). It has damaged houses completely as well as partially. In Jhang (456), Chinot (426) and Hafizabad (393) the completely damaged houses are more whereas partially damaged are also high in Chinot (1531) and Jhang (1620).

In the study region agriculture is main economic activity of the people due the availability of fertile soil and irrigation facility. The 2014-flood has badly affected agriculture sector. During flood, standing crops particularly cotton, rice and sugarcane were prepared to yield. These ready to harvest crops were severely damaged by disastrous inundation. Widespread damages ( $>40 \mathrm{mPKR})$ to agricultural sector were reported in the districts of Jhang, Gujrat, Chinot and Hafizabad (Table 1) because crops were inundated by flood and damaged it completely. Damages to standing crops badly affected the farmer's income level as well as having negative consequences on overall agricultural production.

Mahmood and Razia (2018) also narrated that 2014-flood has caused reduction in crop production mainly in rice and sugarcane by 0.217 million ton and 0.726 million tons respectively. Similarly huge quantity of cotton bales was lost. Beside this, damages to agricultural equipment and loss of stored seeds affected the sector. Likewise, irrigation channels were breached by flood or blocked by siltation which has further affected the agriculture sector.

In the entire study region, livestock is a source of income as well as accomplish the food and nutrition needs of the households. The livestock sector was also severely affected by flood due to significant losses. On the whole, more than 2000 small and large livestock were lost due to flash floods in the upstream areas whereas in lower Chenab Basin flood has caused loss of Buffalos (332), cows (156) and goats (170).

\subsection{Sector Wise Estimated Economic Loss}

The disastrous flood of 2014 has caused damages to human life, structures and properties. The total estimated rehabilitation cost was 1409.295 mPKR. Sector wise detail of the flood damages are given in table 1, which shows that that housing sector suffered the major losses of more than $1000 \mathrm{mPKR}$ followed by agricultural sector with maximum losses to standing crops. Similarly, according to NDMA (2014) flood has caused damages of 180.52 $\mathrm{mPKR}$ to disaster resilience infrastructure (Table 1).

\subsection{Community Based Flood Risk Management}

The Community Based Disaster Risk Management (CBDRM) Approach is applied for possible flood risk reduction strategies. In this regard, response of the community was healthy. The community perception regarding flood risk 
reduction was valuable because of indigenous knowledge. Out of the total respondents, $46 \%$ suggested that embankments at suitable location will reduce the risk of flood in the study region (Table 2). Both constructions of embankments and digging of inundation canals have been suggested by $19 \%$ of the surveyed households. $12.5 \%$ respondents were of view that construction of multipurpose barrages will reduce the risk of flood as well as store water during flood season. Widening and deepening of existing canals is suggested by $7.5 \%$ respondents.

Plantation in upper catchment areas and along river and canals is suggested by $11 \%$.

Table 1 Sector wise economic damages caused by 2014-flood in mPKR

\begin{tabular}{|c|c|c|c|c|c|c|c|c|}
\hline \multirow{3}{*}{$\begin{array}{l}\text { District } \\
\text { Name }\end{array}$} & \multicolumn{2}{|l|}{ Housing } & \multicolumn{5}{|c|}{ Agriculture } & \multirow[t]{3}{*}{ Total } \\
\hline & \multirow[b]{2}{*}{$\begin{array}{l}\text { Completely } \\
\text { Damaged } \\
\text { Houses }\end{array}$} & \multirow[b]{2}{*}{$\begin{array}{l}\text { Partially } \\
\text { Damaged } \\
\text { Houses }\end{array}$} & \multicolumn{3}{|c|}{ Livestock Perished } & \multirow{2}{*}{$\begin{array}{l}\text { Agricultural } \\
\text { Equipments }\end{array}$} & \multirow{2}{*}{$\begin{array}{l}\text { Standing } \\
\text { Crops }\end{array}$} & \\
\hline & & & Buffalos & Cows & Goats & & & \\
\hline Gujrat & 25.55 & 10.44 & 5.24 & 2.45 & 0.735 & 1.991 & 45.398 & 91.8 \\
\hline Sialkot & 109.2 & 46.8 & 8.64 & 1.89 & 0.945 & 1.5 & 16.949 & 185.924 \\
\hline Gujranwala & 40.9 & 63 & 3.2 & 1.19 & 0.49 & 1.92 & 20.821 & 131.521 \\
\hline Mandi B.D & 36 & 6.4 & 0.16 & 0.14 & 0.14 & 0.28 & 0.982 & 44.102 \\
\hline Hafizabad & 137.5 & 72.2 & 7.64 & 2.31 & 3.22 & 7.56 & 41.423 & 271.853 \\
\hline Sarghodha & 14.7 & 8.8 & 0.24 & 0.21 & 0.14 & 0.24 & 1.252 & 25.582 \\
\hline Chinot & 149.1 & 110.3 & 3.2 & 1.61 & 1.575 & 4.82 & 44.373 & 314.978 \\
\hline Jhang & 159.6 & 116.6 & 6 & 3.78 & 2.205 & 3.43 & 51.916 & 343.531 \\
\hline Total & 672.55 & 434.54 & 34.32 & 13.58 & 9.45 & 21.741 & 223.114 & 1409.295 \\
\hline
\end{tabular}

Source: Field Survey 2014

Table 2 Community perception for flood Risk Reduction

\begin{tabular}{|ll|}
\hline Community Suggestions & Community Response (\%) \\
\hline Build embankments & 46 \\
\hline Build embankments and inundation canals & 19 \\
\hline Build barrage & 12.5 \\
\hline Widening and deepening of existing canals & 7.5 \\
\hline Plantation in upper catchment areas & 6 \\
\hline Plantation along the embankments & 5 \\
\hline Removal of silt from canals & 4 \\
\hline Total & 100 \\
\hline
\end{tabular}




\section{Source: Field Survey October, 2014}

\section{Discussion}

Analysis revealed that Pakistan is prone to hydro-meteorological disasters particularly floods (Mahmood 2019). The 2014-flood is generated by the extraordinary late Monsoon activity over the Chenab Basin with rainfall intensity of $18 \mathrm{~mm}$ per day during wet spell which is much higher than the daily average (3mm per day) of the 46 years for the September. Floods have been common and devastating causing damages to lives, properties, standing crops, infrastructure and services (Rahman \& Khan 2011; Mahmood et al. 2016a). So far, 25 major floods have occurred in Pakistan since 1950 whereas in the past two decades the frequency of high flooding events has been increased (Hashmi et al. 2012; Mahmood and Rahman 2019). As a result, individual, household and community vulnerabilitiy have been heightened (Aggarwal 2016). The changing demographic conditions, socioeconomic status and human economic activities in the flood zone have further intensified the vulnerability to floods (Ouma and Tateishi 2014). So, the rising magnitude of flood hazard and socio-economic, physical and attitudinal vulnerabilities has uplifted the flood risk (Mahmood et al. 2019a). Heavy rainfall in monsoon season and melting of snow/glaciers in northern Pakistan (mountainous north) are flood generating factors (Khan 2005; Houze et al. 2011; Shamshad 2011) whereas the poor preparedness and location specific standard structural measures in Indus Basin compel the flood dealing authorities to breach the emabankement in order to protect barrages and main cities (Mahmood et al., 2019b).

Analysis also revealed that on average the monthly income of the household is less than 20000PKR. More than half of the households have monthly income less than 15000PKR. Similarly, about 18.4 percent of the households have small family size. More than 90 percent of the houses are made of mud which is not resilient to flood. The social vulnerable groups based on gender and age constitute of more than 60 percent. The estimated female population is 49 percent. Less than 10 years age group and above 50 years age group people are 12 and 9 percent, respectively. This situation has further increased the vulnerability of the exposed communities to flood. The high vulnerabilities of exposed communities have further heightened the flood risk. The number of affected population is directly linked to the spatial extent of flood. As the spatial extent and depth of flood is increasing downstream in the same manner affected population is increasing. Jhang is most affected district followed by Hafizabad.

Structural measures are highly needed in the entire lower Chenab Basin. Similarly, inundation canals will rechange the ground water level and reduce the flood rsik.

Analysis further revealed that infrastructure was badly affected by 2014-flood in the entire study region. It has undercut foundation of the non-resilient buildings and damaged hundreds of buildings in the entire region. The irrigation canals were breached by high discharge as well as roads and irrigation channels. More than 95percent of the affected villages are located on both sides of Chenab River where majority of the people are living in nonresilient mud or mud-break (Kacha) houses. The exposed and non-resilient houses were completly damaged by flood. Spatially, these houses are located in flood zone. Still the risk of potential damages is prevailing because the affected population has built their houses again over the same location. The spatial extent and depth of the flood are main characters in the destruction of houses and standing crops. The damages were maximum in Hafizabad, Chinot and Jhang with estimated economic loss of 271.8, 315 and $343 \mathrm{mPKR}$, respectively. The spatial extent, depth and magnitude of flood were variable from Head Marala to Head Trimmu in the study region. The extent and depth is increasing from north to south. Similarly, the extent of damages to human life, houses, agriculture sector is increasing towards south. Hafizabad, Chinot and Jhang are the most affected districts in the south of the study 
region. Agriculture and housing are the most affected sectors because the amin economic activitiy of the local residents is agricultural activitiy due to the availability of fertilte land and water. The houses are made of nonresilient material in the flood zone and esily get damaged by flood.

Analysis further revealed that the flood forecasting and zonation of flood risk zones using probabilistic and spatial hydrological approaches will identify the exposed, susceptible and vulnerable communities (Mahmood et al. 2019a). Riverine floods often burst the river banks and take away huge farmland and damage vulnerable houses and structures. However, deposition of silt and clay which may increase crop fertility but the deposition of sand completely destroys farmland. The Chenab flood plain is formed by the sediment yield deposited by the river. But flood has damaged the crop land by depositing sand on the land. On average, about 2.8feet thick layer of sand was observed over the farmland in Hafizabad and more than $3.5 f e e t$ in the Chinot and Jhang. The recovering of fertile land from such sand needs time and financial resources. GIS and Remote Sensing are the effective geospatial tools for analysis and management.

In short, exposure and vulnerability to floods is very high because population clusters are located in high-risk areas, where the individuals, households and community vulnerabilities are high. Similarly, construction in flood zone, low literacy level, high poverty, lack of social cohesion, and awareness further growing vulnerability of the exposed communities lead to high risk. Forecasting the magnitude of 100years, 125years and 150years extreme rainfall events, surface runoff and floods, delineation of high risk zone, identification communities and structures exposed to potential damages are important non-structural measures to reduce flood risk. Similarly, high resolution Digital Elevation Model (DEM) will help to identify suitable locations for inundation canals. These canals will not only reduce the flood risk but also recharge the groundwater level.

\section{Conclusions}

It is concluded from the analysis that flood is one of the recurrent hydrological hazards in Chenab Basin. The 2014-flood was generated by extraordinary late Monsoon activity over the upper catchment areas of Chenab Basin having intensity of $16 \mathrm{~mm}$ /day during wet spell which is much higher than the daily average (2.8mm per day) of the past 40 years normal for the September. Flash flood dominates the upper reches while in the lower reaches riverine flooding is common. The spatial extent, depth and damages of 2014-flood the lower Chanab Basin forms two distinct zones. The flood overtopped the banks and caused damages to fully grown standing crops, infrastructure, sources of livelihood and human life losses. Based on spatial extent the study region is delineated into upper and lower zone. The upper zone comprised of districts of Gujrat, Gujranwala, Sialkot, Mandi Bahaudin and Sarghodha where the average spatial extent of flood is $0.92 \mathrm{Km}$ with average depth is $1.2 \mathrm{~m}$ and estimated economic loss is approximately $92 \mathrm{mPKR}$. The lower zone comprised of districts of Hafizabad, Chinot and Jhang where the average spatial extent of flood is $3.4 \mathrm{Km}$ with average depth is $2.8 \mathrm{~m}$ and estimated economic loss is over $300 \mathrm{mPKR}$. Greater the spatial extent and more depth leads to more damages.

It is also concluded from the analysis that heavy and prolong rainfall in summer is a major factor responsible for the genesis of flood disaster. In addition to this, excessive melting of snow and glacier, cloud bursting and deposition of silt, clay and sand in river channels are the major physical factors responsible for generation of floods. The spatial extent of aggressive weather events have also been grown during the last two decades. The significant increase in extream rainfall events and excessive melting of snow caps and glaciers in the headwater region, anthropogenic activities on the active flood plain and breaching of embankments have further increased the risk flood and potential damages. 
There are some human flood intensifying factors including human encroachments onto the active flood plain, bursting of temporary dams behind the bridges, clearing of forests for infrastructure development, increasing exposure of impermeable soil are some of the key anthropogenic factors. These factors have also grown the extent of damages. Therefore, there is a need of policy response for the land use regulation to check encroachments onto the channel and watershed management as a flood abatement measure to reduce the risk of future mega flood events. The analysis further indicates that there is a constant fluctuation in both the rainfall and river runoff, which is a clear signal of climate change.

Flood risk reduction plan based on hydro-meteorological conditions, geo-morphometric characteristics, hydrological reactions of the basin to rainfall event and community perception is highly recommended. The installation of sensor based hydro-gauging stations, automatic weather stations and Doppler weathers radar for effective flood forecasting and early warning system is also the need of such basin located in the Monsoon regime. Similarly, geo-spatial assessment of flood risk using high resolution spatial data is needed for flood risk zonation and as strategy for flood risk reduction. Disaster preparedness and resilience activities specific to flood risk zones are also suggested as flood risk reduction strategies. Increasing retention capability of the basin by plantation in the upper catchment area is needed on emergency basis. Similarly, check dams are also important

flood risk eduction strategy in upper reaches. Identification of suitable site for construction multi-purpose barrage and inundation canals are utmost important. This will not only reduce the risk of flood but also recharge the groundwater.

\section{Declarations}

\section{Authors Contributions}

Mahmood, S and Rani, R has contributed equally in this research work.

\section{Funding}

No funding

\section{Competing Interests}

No competing interest

\section{Availability of data and materials}

Data is available in the manuscript in the form of maps, tables and graphs. The data will also be made available on request.

\section{References}

Aggarwal, A. (2016). Exposure, hazard and risk mapping during a flood event using open source geospatial technology. Geomatics, Natural Hazards and Risk, 7(4), 1426-1441.

Ahmad, I., Tang, D., Wang, T., Wang, M., Wagan, B. (2015). Precipitation trends over time using Mann-Kendall and spearman's rho tests in swat river basin, Pakistan. Advances in Meteorology 2015.

https://doi.org/10.1155/2015/431860. 
Beyene T, Lettenmaier DP, Kabat P (2010) Hydrologic impacts of climate change on the Nile River Basin: implications of the 2007 IPCC scenarios. Climate Change 100(3-4):433-461.

Booij, M. J. (2005). Impact of climate change on river flooding assessed with different spatial model resolutions. Journal of hydrology, 303(1-4), 176-198.

Dang, N. M., Babel, M. S., \& Luong, H. T. (2011). Evaluation of food risk parameters in the day river flood diversion area, Red River delta, Vietnam. Natural hazards, 56(1), 169-194.

Dawood, M., Rahman, A. U., Ullah, S., Mahmood, S., Rahman, G., \& Azam, K. (2020). Spatio-statistical analysis of rainfall fluctuation, anomaly and trend in the Hindu Kush region using ARIMA approach. Natural Hazards, 1-16.

Gaurav K, Sinha R, Panda, P.K. (2011). The Indus flood of 2010 in Pakistan: a perspective analysis using remote sensing data. Natural Hazards 59:1815-1826.

Gholami, V., Jokar, E., Azodi, M., Zabardast, H. A., \& Bashirgonbad, M. (2009). The influence of anthropogenic activities on intensifying runoff generation and flood hazard in Kasilian watershed. Journal of Applied Sciences, $9(20), 3723-3730$.

GoP (Government of Pakistan) 2014. Annual flood report 2014. Ministry of Water \& Power, Office of the Chief Engineering advisor \& chairman federal flood commission Islamabad.

Hashmi HN, Siddiqui QTM, Ghumman AR, Kamal MA, Mughal HR (2012) A critical analysis of 2010 floods in Pakistan. Afr J Agric Res 7:1054-1067.

Hirabayashi, Y., Mahendran, R., Koirala, S., Konoshima, L., Yamazaki, D., Watanabe, S., ... \& Kanae, S. (2013). Global flood risk under climate change. Nature Climate Change, 3(9), 816-821.

Houze, R. a., Rasmussen, K. L., Medina, S., Brodzik, S. R., \& Romatschke, U. (2011). Anomalous Atmospheric Events Leading to the Summer 2010 Flood in Pakistan. Bulletin of the American Meteorological Society, 92(3), $291-298$.

Hussain, M. S., \& Lee, S. (2014). Long-term variability and changes of the precipitation regime in Pakistan. AsiaPacific Journal of Atmospheric Sciences, 50(3), 271-282

IPCC (2014). Climate change 2014: Synthesis Report. Contribution of Working Groups I. II and III to the Fifth Assessment Report of the Intergovernmental Panel on Climate Change (IPCC) Geneva, Switzerland, 151.

Jonkman, N. S, Vrijling, K. J (2008) 'Losses of life due to floods'. J Flood Risk Management. 1. 43-56

Jonkman, S. N., \& Kelman, I. (2005). An analysis of the causes and circumstances of flood disaster deaths. Disasters, 29(1), 75-97.

Khan A,. N. (2005).An Assessment of Floods Hazard Causes for Efficient Flood plain Management : A Case of Neelam-Jehlum Valley : Pakistan Geographical Review, 60(1), 42-53

Khan SI, Hong Y, Gourley JJ, Khattak MU, Groeve TD (2014) Multi-sensor imaging and space-ground crossvalidation for 2010 flood along Indus River, Pakistan. Remote Sensing 6:2393-2407 
Kosaka,Y.,\&Xie, S. P. (2013). Recent global-warming hiatus tied to equatorial Pacific surface cooling. Nature, 501(7467), 403-407.

Mahmood, S \& Rahman, A. (2019a). Flash Flood Susceptibility Modelling using Geo-morphometric and Hydrological Approaches in Panjkora Basin, Eastern Hindu Kush, Pakistan. Environmental Earth Sciences, 78,(1) 43-58.

Mahmood, S \& Rani, R. (2018). Extent of flood damages in Chenab Basin, Upper Indus Plain" in "Natural Hazards Risk Assessment and Vulnerability Reduction", DOI: 10.5772/intechopen.79687, ISBN 978-953-51-6297-1.

Mahmood, S. (2019). Flood Risk Modelling and Management in Panjkora Basin, Eastern Hindu Kush, Pakistan (Doctoral dissertation, University of Peshawar, Peshawar.).

Mahmood, S., \& Hamayon, K. (2021). Geo-spatial assessment of community vulnerability to flood along the Ravi River, Ravi Town, Lahore, Pakistan. Natural Hazards, 1-20.

Mahmood, S., \& Rahman, A. (2019b). Flash flood susceptibility modelling using geomorphometric approach in the Ushairy Basin, eastern Hindu Kush. Journal of Earth System Science, 128(4), 97.

Mahmood, S., Khan, A. H., \& Mayo, S. M. (2016a). Exploring underlying causes and assessing damages of 2010 flash flood in the upper zone of Panjkora River. Natural Hazards, 83(2), 1213-1227.

Mahmood, S., Khan, A. H., \& Ullah, S. (2016b). Assessment of 2010 flash flood causes and associated damages in Dir Valley, Khyber Pakhtunkhwa Pakistan. International Journal of Disaster Risk Reduction, 16, $215-223$.

Mahmood, S., Rahman, A \& Sajjad, A. (2019a). Assessment of 2010 flood disaster causes and damages in district Muzaffargarh, Central Indus Basin, Pakistan. Environmental Earth Sciences. 78, (3) 1-11.

Mahmood, S., Rahman, A. U., \& Shaw, R. (2019b). Spatial appraisal of flood risk assessment and evaluation using integrated hydro-probabilistic approach in Panjkora River Basin, Pakistan. Environmental monitoring and assessment, 191(9), 573.

Mahmood, S., Sajjad, A., \& Rahman, A. U. (2021). Cause and damage analysis of 2010 flood disaster in district Muzaffar Garh, Pakistan. Natural Hazards, 1-12.

Manzoor, M., Bibi, S., Manzoor ,M., \&Jabeen, R. (2013). Historical Analysis of flood Information and Impacts Assessment and Associated Response in Pakistan (1947-2011),5(3),139-146.

Ouma, Y. O., \& Tateishi, R. (2014). Urban flood vulnerability and risk mapping using integrated multi-parametric AHP and GIS: methodological overview and case study assessment. Water, 6(6), 1515-1545.

Rahman, A., \& Khan, A. N. (2011). Analysis of flood causes and associated socio-economic damages in the Hindu Kush region. Natural Hazards, 59(3), 1239-1260.

Rahman, A., \& Khan, A. N. (2013). Analysis of 2010-flood causes, nature and magnitude in the Khyber Pakhtunkhwa, Pakistan. Natural Hazards, 66(2), 887-904. 
Rahman, A., \& Shaw, R. (2015). Floods in the Hindu Kush Region: causes and socio-economic aspects. In Mountain Hazards and Disaster Risk Reduction (pp. 33-52). Japan: Springer.

Rahman, S., \& Shah, M. A. (2012). Rainfall Trends in Different Climate Zones of Pakistan, Pakistan Journal of Meteorolgy, 9,37-47.

Shamshad, A. (2011). The South Asiatic Monsoon and Flood Hazard in the Indus River Basin, Pakistan. Basic and AppliedScience7:101-115.

Syvitski, J. P., \& Brakenridge, G.R. (2013). Causation and avoidance of catastrophic flooding along the Indus River, Pakistan. GSA Today 23(1):4-10

Tariq, M., A., \& Giesen, V. (2012). Floods and flood management in Pakistan. Phys Chem Earth 47-48:11-20. doi:10.1016/j.pce.2011.08.014

Vetter T, Reinhardt J, Flörke M, van Griensven A, Hattermann F, Huang S et al (2017) Evaluation of sources of uncertainty in projected hydrological changes under climate change in 12 large-scale river basins. Clim Change 141(3):419-433

Wang, S. Y., Davies, R. E., Huang, W.R., \& Gillies, R. R. (2011). Pakistan's two-stage monsoon and links with the recent climate change, journal of Geographical Research, 116, 1-15.

Zaman, Q., \& Afzal, M. (2013).Temporal Trends in the Peak Monsoon Precipitation Events over Northeast Pakistan, 10(19), 19-30.

\section{Figures}




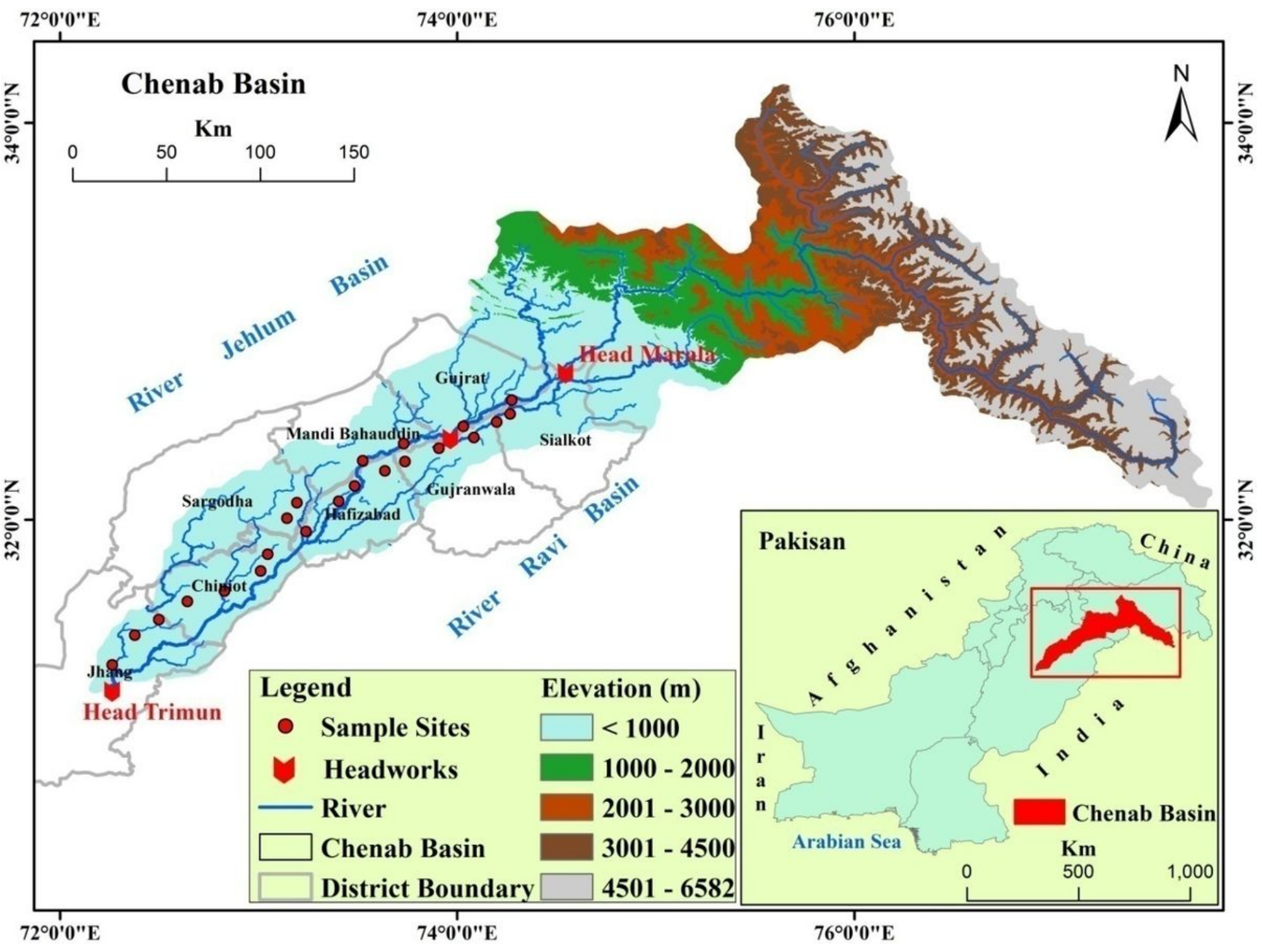

Figure 1

Location of the study area and sample sites 


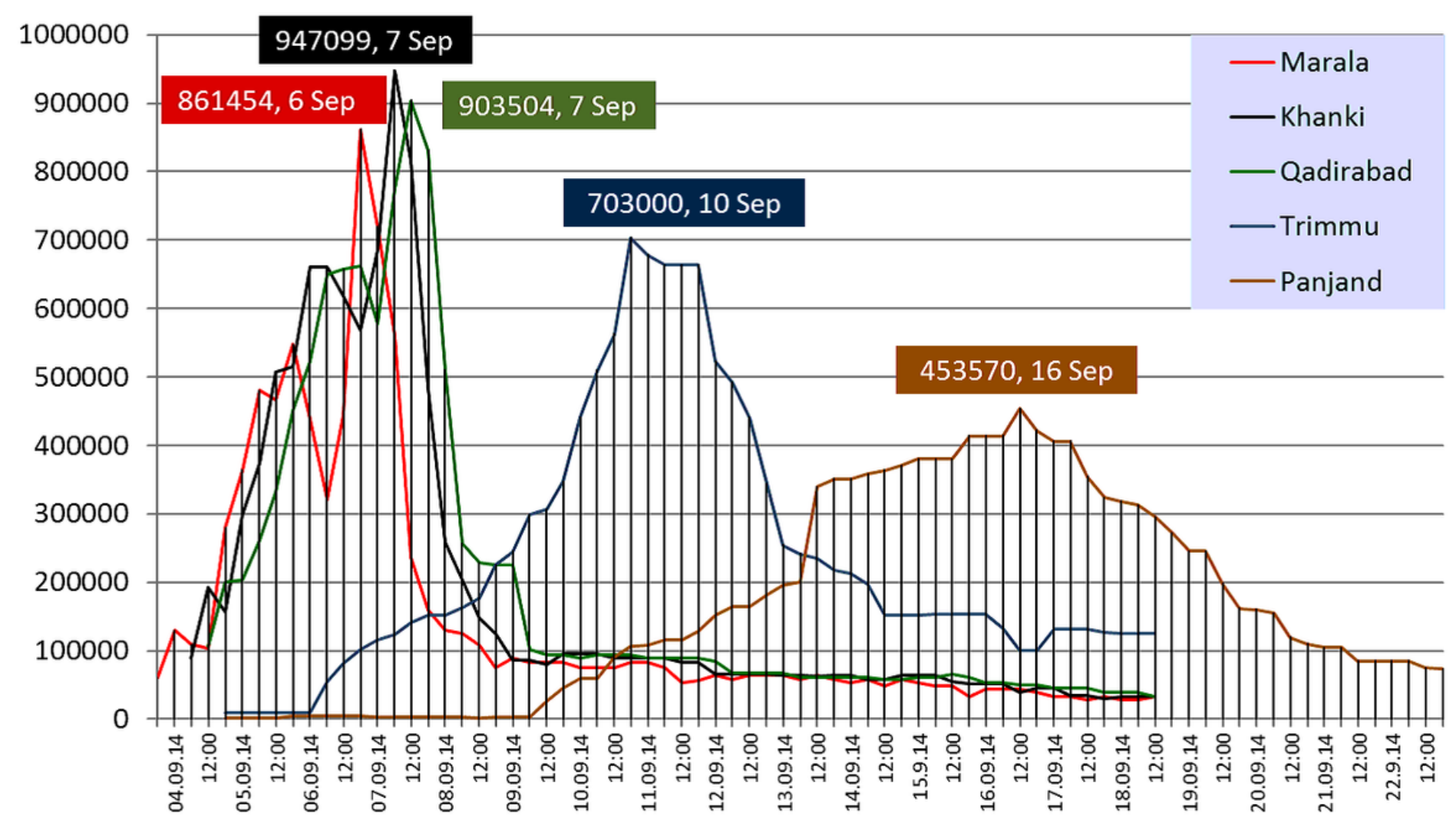

Figure 2

Flood peaks in cusecs (Source: GoP 2014) 


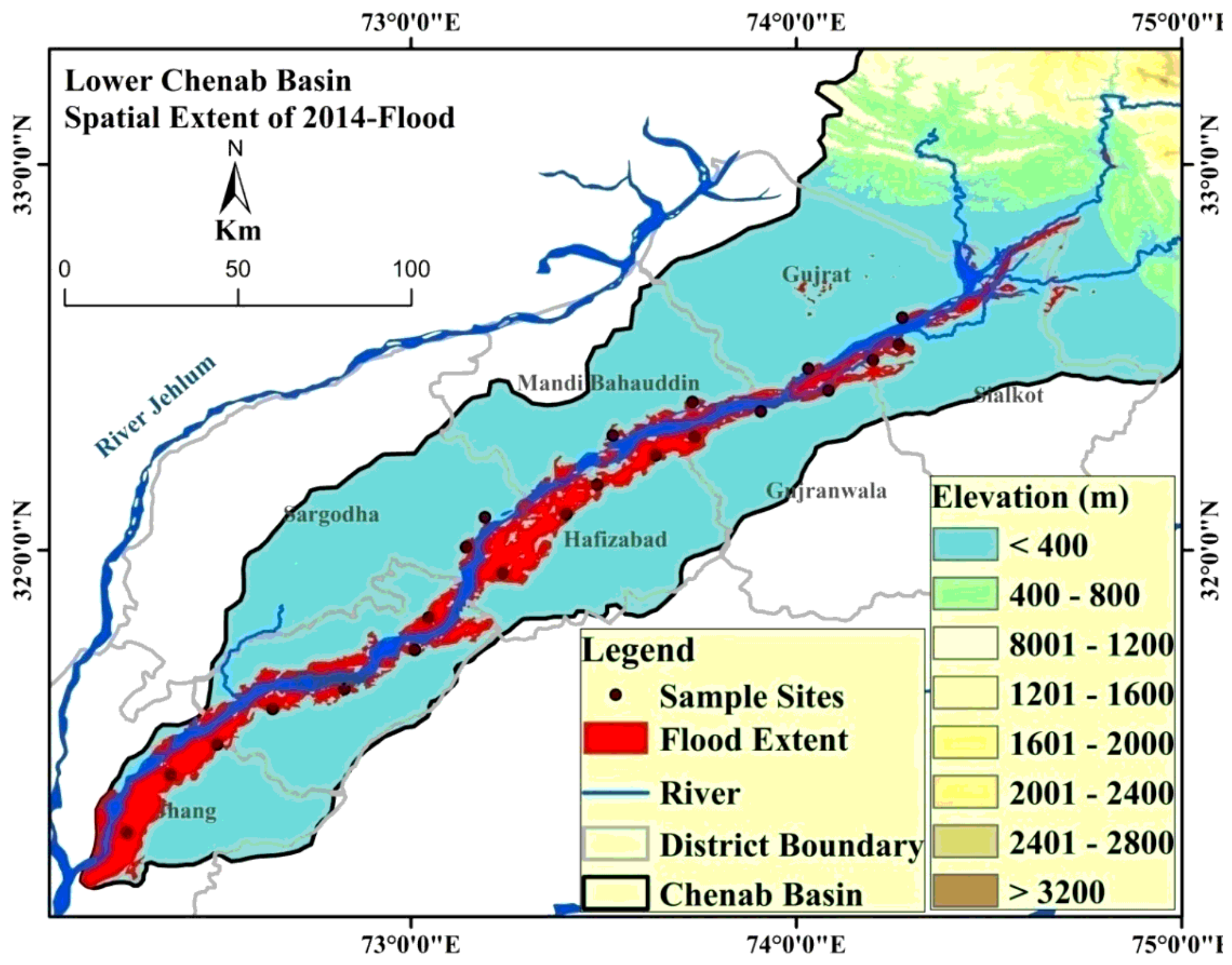

Figure 3

Spatial extent of 2014 flood extracted from MODIS satellite image 


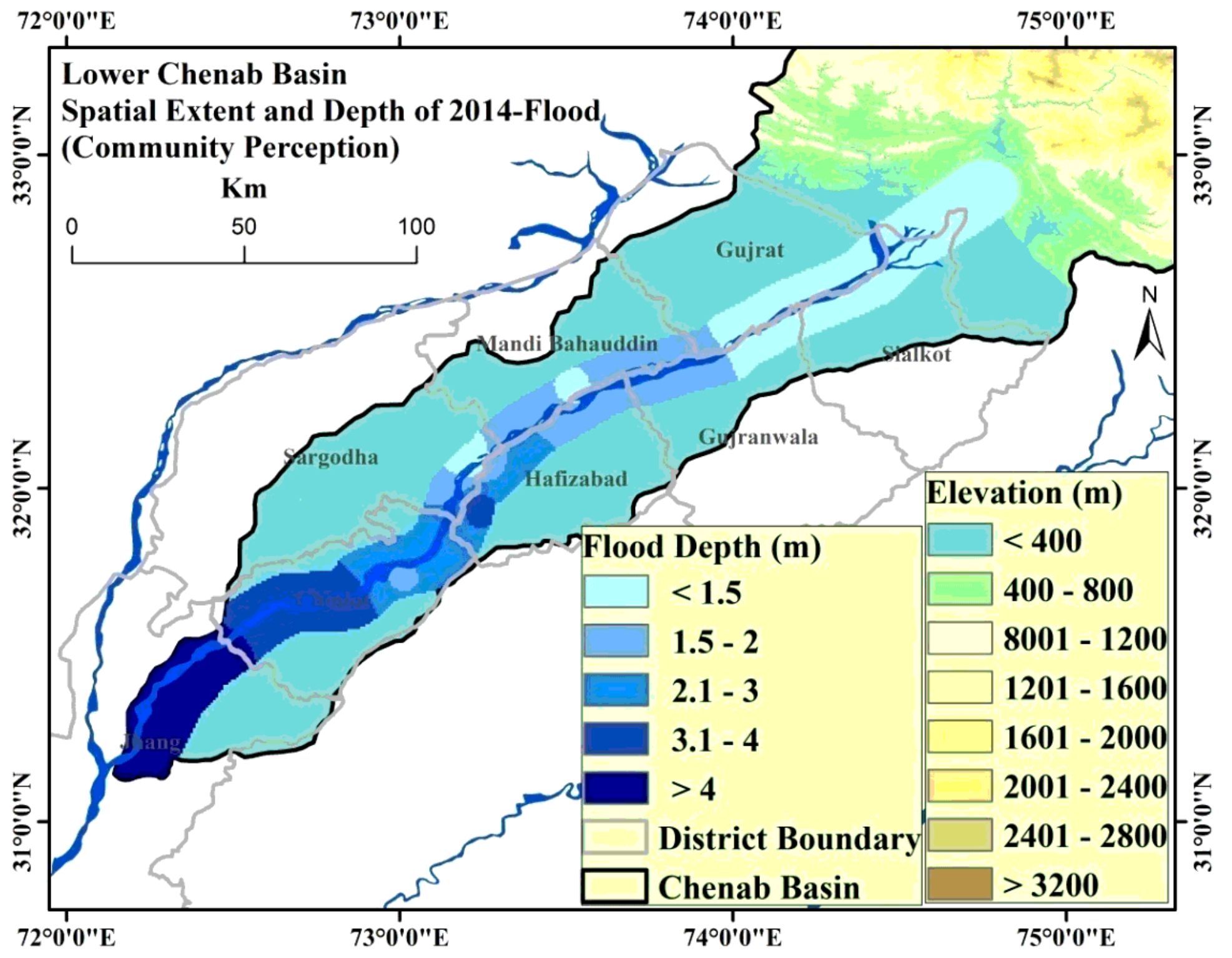

Figure 4

Spatial extent and vertical profile of 2014 flood 


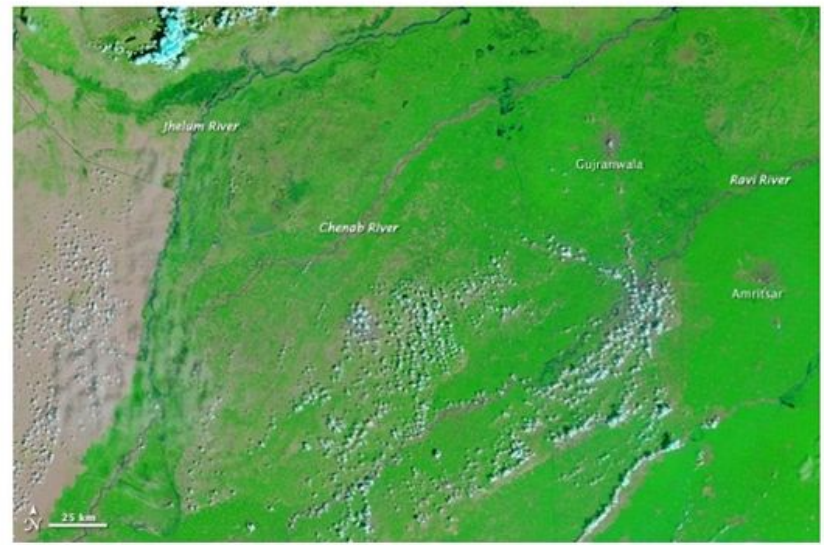

Figure 5a. Pre-flood View Captured by Moderate Resolution Imaging Spectroradiometer (Source: NASA, 31/08/2014)

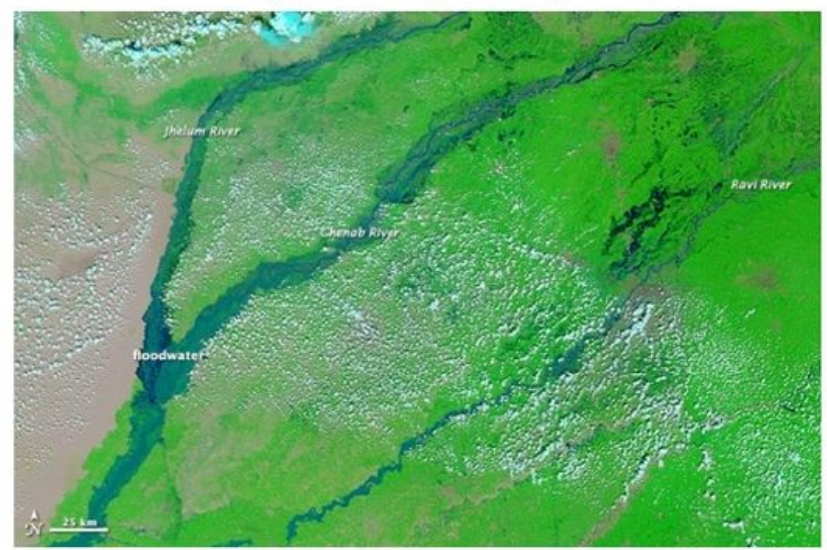

Fig. 5b. Post-flood View Captured by Moderate Resolution Imaging Spectroradiometer (Source: NASA, 11/09/2014)

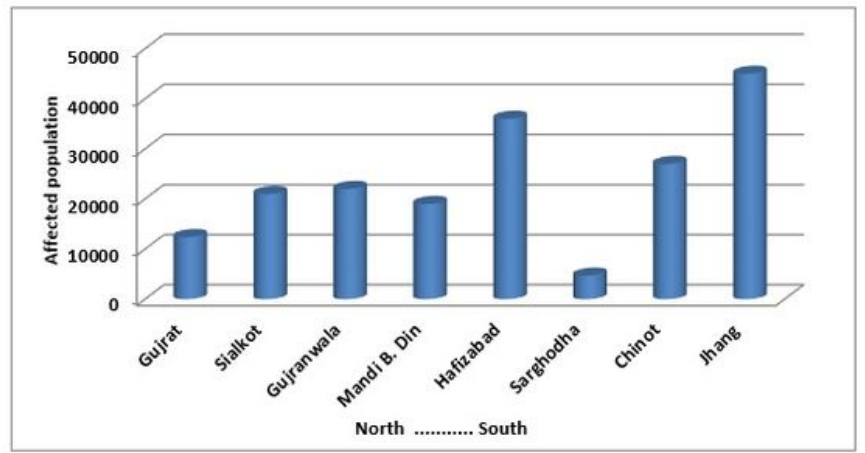

\section{Figure 5}

Figure 5a. Pre-flood View Captured by Moderate Resolution Imaging Spectroradiometer (Source: NASA, 31/08/2014). Fig. 5b. Post-flood View Captured by Moderate Resolution Imaging Spectroradiometer (Source: NASA, 11/09/2014). Distribution of affected population 


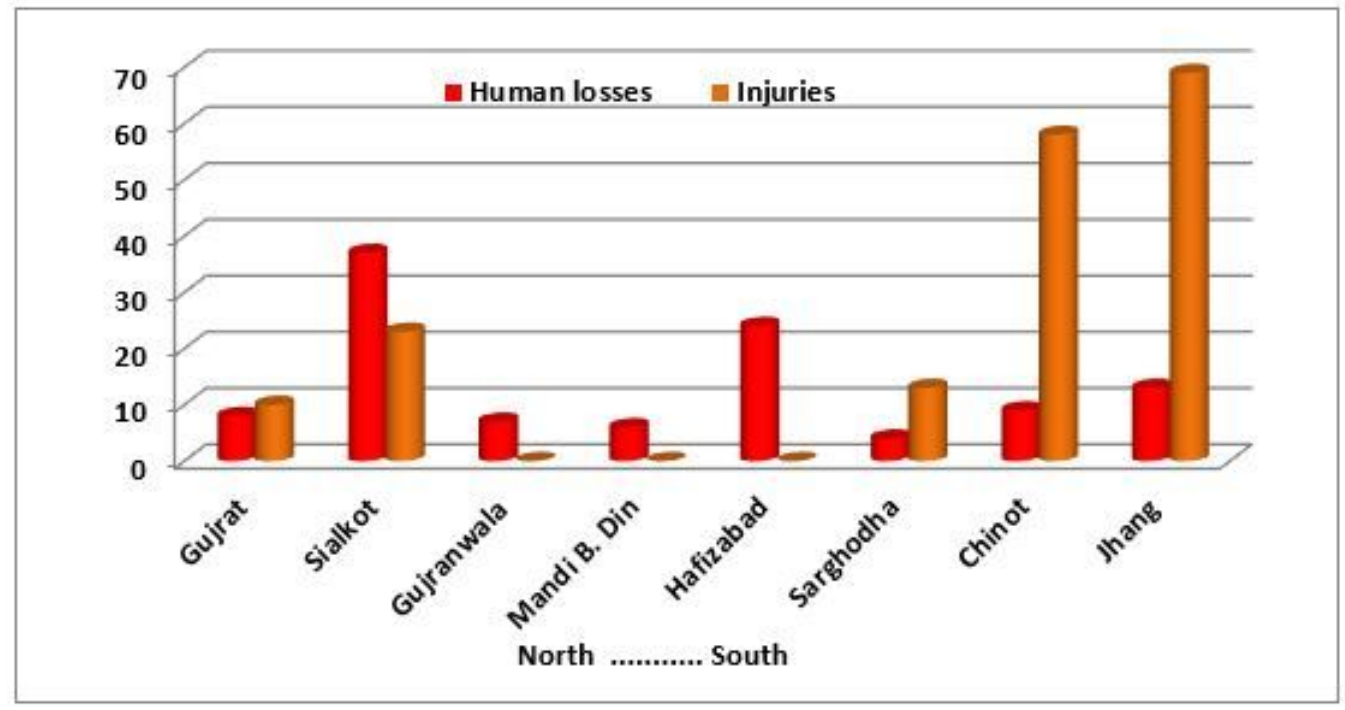

Figure 6

Distribution of human losses and injuries

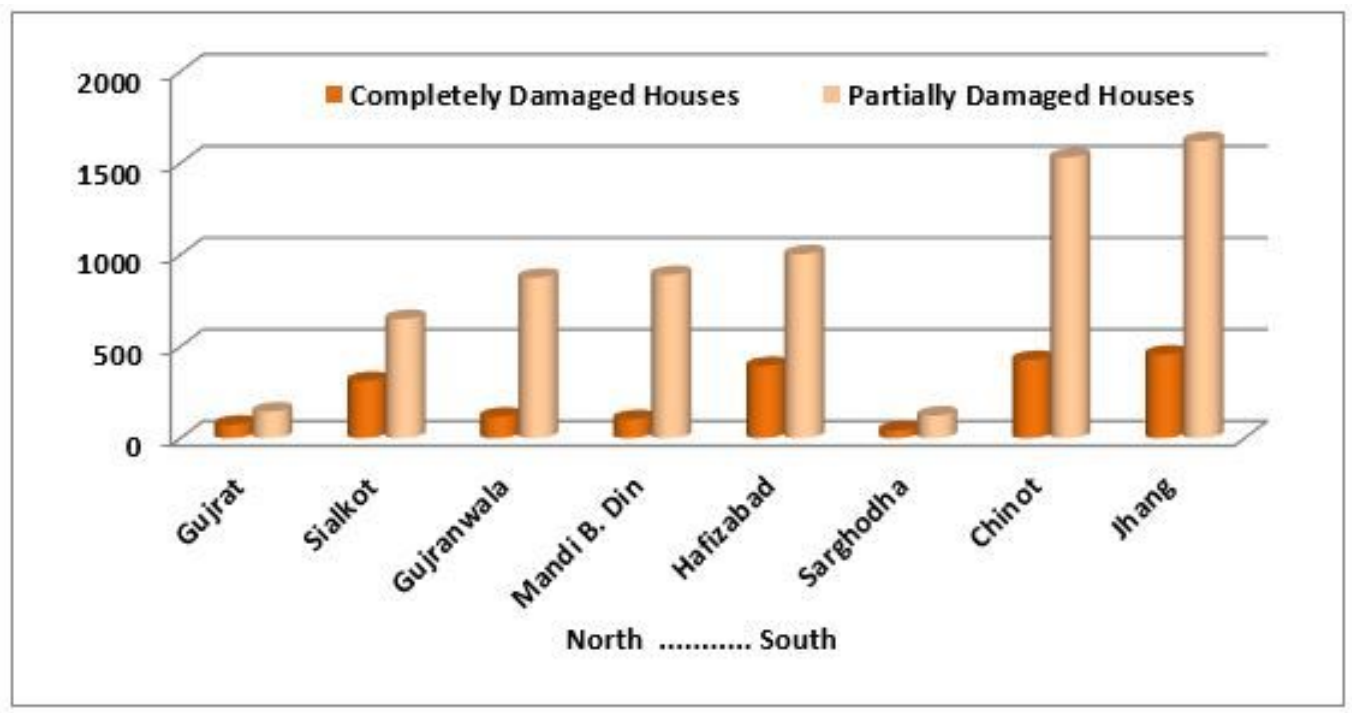

Figure 7

Distribution of damaged houses 